\title{
PENERAPAN MODEL PEMBELAJARAN NUMBERED HEADS TOGETHER (NHT) UNTUK MENINGKATKAN MOTIVASI DAN PRESTASI BELAJAR IPS SISWA SMP NEGERI 1 NGRAYUN PONOROGO
}

\author{
Anugerah Eko Pratomo \\ SMP Negeri 1 Ngrayun \\ Email: anugerah.pratomo@gmail.com
}

\begin{abstract}
Abstrak
Penelitian ini bertujuan untuk meningkatkan motivasi dan prestasi belajar IPS siswa SMPN 1 Ngrayun melalui penerapan model pembelajaran Numbered Heads Together (NHT). Penelitian ini menggunakan Penelitian Tindakan Kelas. Subyek penelitiannya adalah siswa kelas VIII A SMP Negeri 1 Kecamatan Ngrayun. Pengumpulan data dilakukan dengan menggunakan tes, wawancara, dan observasi. Teknik keabsahan data dengan teknik triangulasi metode. Teknis analisis dilakukan kualitatif interaktif. Hasil penelitian menunjukan bahwa penerapan model pembelajaran NHT dalam pembelajaran IPS dapat meningkatkan prestasi belajar siswa kelas VIII A SMP Negeri 1 Kecamatan Ngrayun. Peningkatan motivasi belajar siswa dapat diketahui dari hasil angket motivasi belajar siswa setelah pelaksanaan tindakan, pada siklus I mencapai 50\%, siklus II meningkat menjadi 69,23\%, dan siklus III meningkat menjadi 84,62\%. Sementara prestasi belajar siswa pada kondisi awal menunjukkan bahwa nilai rata-rata sebesar 68,27 dengan ketuntasan klasikal 53,85\%, setelah dilakukan tindakan pada siklus I mengalami peningkatan nilai rata-rata menjadi 73,85 dengan ketuntasan klasikal sebesar 65,38\%, siklus II meningkat dengan nilai rata-rata 74,23 dengan ketuntasan klasikal sebesar 69,23\%, dan pada siklus III mengalami peningkatan kembali, dengan nilai rata-rata mencapai sebesar 80,38 dengan ketuntasan klasikal mencapai $88,46 \%$.
\end{abstract}

Kata kunci : IPS, motivasi belajar, NHT, prestasi belajar

The Application of Numbered Heads Together Model to Improve Students' Motivation and Learning Achievement on Social Science at SMP Negeri 1 NgrayunPonorogo

\begin{abstract}
The study aims to improve Students' Motivation and Learning Achievement on Social Science at SMPN 1 Ngrayun Ponorogo through applying Numbered Heads Together (NHT). It used classroom action research. The subject of the research was students of class VIII A, SMPN 1 Ngrayun district. Data were collected by using test, interview, and observation. The data were verified through method triangulation. The data, then, analyzed by using interactive qualitative. The results show that the application of Numbered Head Together (NHT) on Social Science can improve students' learning achievement of students of class VIII A, SMPN 1 Ngrayun. Meanwhile, the improvement of the students' motivation can be seen from questionnaire of students' motivation after applying NHT. In the cycle 1, the students' motivation reaches at $50 \%$, it increasesat $69.23 \%$ in the cycle 2 and in the cycle 3, it increases higher at $84.62 \%$. The students' prior learning achievement is at the average score of 68.27 with classical achievement at 53.85 $\%$. After applying NHT, the students' learning achievement score increases at 73.85 with the classical achievement of $65.38 \%$ in the cycle 1. It increases more at average score of 74.23 with the classical achievement of $69.23 \%$ in the cycle 2. It, then, reaches higher at average score of 80.38 with the classical achievement of $88.46 \%$ in the cycle 3.
\end{abstract}

Keywords: learning motivation, learning achievement, NHT, social science 
Avaliable online at http://e-journal.unipma.ac.id/index.php/gulawentah

\section{Pendahuluan}

Pembelajaran IPS bertujuan membentuk warga negara yang berkemampuan sosial dan yakin akan kehidupannya sendiri di tengah-tengah kekuatan fisik dan sosial, yang pada gilirannya akan menjadi warga negara yang baik dan bertanggung jawab (Gunawan, 2013:48-49). Namun demikian dalam kenyataannya IPS belum dapat berfungsi secara optimal sebagaimana seharusnya. Hal ini menegaskan bahwa hingga saat ini penyelenggaraan pembelajaran IPS di tingkat sekolah masih bermasalah. Selama ini pembelajaran IPS terutama di sekolah kurang diminati oleh siswa. Pelajaran IPS dianggap sebagai pelajaran yang membosankan karena seolah-olah cenderung hafalan. Kebanyakan siswa menganggap bahwa IPS tidak membawa manfaat jika dibandingkan ilmu alam ataupun matematika misalnya. Oleh karena itu, pelajaran IPS hanya dianggap sebagai pelengkap, sehingga tidak mengherankan jika prestasi belajar IPS siswa juga cenderung kurang memuaskan. Keadaan seperti tersebut juga terjadi pada siswa kelas VIII A SMP Negeri 1 Ngrayun Kabupaten Ponorogo. Berdasarkan hasil ulangan harian kelas VIII A pemahaman terhadap pelajaran IPS masih tergolong rendah. Hal ini dapat dilihat dari beberapa nilai ulangan harian yang telah dilaksanakan pada semester ganjil tahun pelajaran 2013/2014 sebesar 69, sedangkan kriteria ketuntasan minimal (KKM) ditentukan 75 .

Rendahnya prestasi belajar siswa dalam pembelajaran IPS sebagaimana disampaikan diatas diakibatkan oleh banyak faktor, baik faktor internal maupun faktor eksternal. Misalnya terkait dengan penyajian materi pelajaran yang kurang menarik sehingga cenderung membosankan, kurangnya sarana prasarana yang mendukung, dan metode pembelajaran yang kurang sesuai dengan substansi materi. Selain hal tersebut, rendahnya kualitas pembelajaran IPS Sejarah menurut penelitian Akhmad Arif Musadad dan Wasino antara lain sebagai berikut: (1) guru kurang mampu melaksanakan prosedur pembelajaran dengan benar; (2) penyampaian materi didominasi oleh metode ceramah; (3) guru hanya menjelaskan materi yang persis sama seperti yang tertulis di buku teks, tanpa ada upaya improvisasi atau pengembangan yang dapat membangkitkan minat dan motivasi siswa; (4) guru juga tidak mencoba menanamkan nilai-nilai, sikap, dan keterampilan sosial yang relevan, yang bermanfaat dalam kehidupan siswa sebagai warga masyarakat dan warga negara; (5) aktivitas belajar siswa rendah, hal ini tercermin dari siswa pasif dalam mengikuti pelajaran, tidak ada yang bertanya, bahkan kalau ditanya tidak ada yang menjawab, kalau ditunjuk baru menjawab, dengan jawaban yang sekenanya; dan (6) situasi pembelajaran kurang kondusif. (Musadad dan Wasino, 2012:230).

Selain prestasi belajar rendah, berdasarkan pengamatan yang peneliti lakukan terhadap siswa kelas VIII A SMP Negeri 1 Ngrayun Kabupaten Ponorogo pada saat mengikuti kegiatan pembelajaran IPS, motivasi belajar siswa 
juga rendah, hal ini tercermin pada saat kegiatan pembelajaran berlangsung banyak siswa yang berbicara sendiri dengan temannya, sebagian siswa mengantuk saat mengikuti kegiatan pembelajaran, dan tidak memperhatikan penjelasan yang diberikan guru.

Dari hal tersebut di atas dapat disimpulan bahwa keadaan pembelajaran IPS belum baik. Untuk memecahkan masalah pembelajaran yang demikian, dari hasil diskusi dengan mitra kolaborator perlu dilakukan upaya berupa pengembangan pembelajaran. Pengembangan pembelajaran yang diperlukan saat ini adalah pembelajaran yang kreatif dan inovatif yang melibatkan peran siswa secara aktif dalam kegiatan pembelajaran. Dewasa ini kajian dan pembaharuan teknologi pendidikan mengutamakan pola berpusat pada kepentingan subjek belajar atau student centered. (Purwanto, 1994:34). Untuk itu perlu diupayakan suatu model pembelajaran kooperatif tipe Numbered Heads Together (NHT) yang diharapkan dapat meningkatkan motivasi dan prestasi belajar siswa IPS dan sekaligus juga memberikan iklim yang kondusif dalam perkembangan daya nalar siswa.

Menurut Johnson dan Johnson (dalam Huda, 2011:31) pembelajaran kooperatif berarti working together to accomplish shared goals (bekerjasama untuk mencapai tujuan bersama). Dalam suasana kooperatif, setiap anggota samasama berusaha mencapai hasil yang nantinya bisa dirasakan oleh semua anggota kelompok. Dalam konteks pengajaran, pembelajaran kooperatif sering kali didefinisikan sebagai pembentukan kelompok-kelompok kecil yang terdiri dari siswa-siswa yang dituntut untuk bekerjasama dan saling meningkatkan pembelajarannya dan pembelajaran siswa-siswa lain ( Huda, 2011:31).

Dalam review-nya terhadap 26 penelitian yang dilaksanakan dari 1971 sampai 1984, misalnya Johnson dan Johnson (dalam Huda, 2011:14) menegaskan bahwa pembelajaran kooperatif dapat meningkatkan prestasi belajar dan interaksi sosial antar siswa. Demikian juga Slavin (dalam Miftahul Huda, 2011:15) dalam review-nya terhadap 60 penelitian yang mengobservasi pembelajaran kooperatif di SD dan SMP antara tahun 1972 sampai 1987, menemukan bahwa pembelajaran kooperatif dapat menjadi metode efektif untuk meningkatkan prestasi siswa.

Stahl (dalam Isjoni, 2011:12) menyatakan bahwa cooperative learning (pembelajaran kooperatif) dapat meningkatkan belajar siswa lebih baik dan meningkatkan sikap tolong menolong dalam perilaku sosial. Juliati (dalam Isjoni, 2011:12) mengemukakan bahwa pembelajaran kooperatif lebih tepat digunakan pada pembelajaran IPS. Penelitian yang dilakukan Webb (dalam Solihatin 2011:13) menemukan bahwa dalam pembelajaran dengan menggunakan model cooperative learning, sikap, dan perilaku siswa berkembang ke arah suasana demokratisasi dalam kelas. Di samping itu, penggunaan kelompok kecil siswa mendorong siswa lebih bergairah dan termotivasi dalam mempelajari IPS. Belajar dengan model kooperatif dapat diterapkan untuk memotivasi siswa 
gulawentah: Jurnal Studi Sosial

Volume 2 Nomor 1 Juli 2017 hal 1-12

Avaliable online at http://e-journal.unipma.ac.id/index.php/gulawentah

berani mengemukakan pendapatnya, menghargai pendapat teman, dan saling memberikan pendapat (sharing ideas). Selain itu dalam belajar biasanya siswa dihadapkan pada latihan soal-soal atau pemecahan masalah. Oleh sebab itu cooperative learning sangat baik untuk dilaksanakan karena siswa dapat bekerjasama dan saling tolong menolong mengatasi tugas yang dihadapinya. Dalam cooperative learning, siswa terlibat aktif pada proses pembelajaran sehingga memberikan dampak positif terhadap kualitas interaksi dan komunikasi yang berkualitas, dapat memotivasi siswa untuk meningkatkan prestasi belajarnya (Isjoni, 2011:13).

Bertolak dari uraian di atas maka peneliti akan melakukan penelitian tindakan kelas dengan mengambil judul "Penerapan Model Pembelajaran Kooperatif Tipe Numbered Heads Together (NHT) untuk Meningkatkan Motivasi dan Prestasi Belajar IPS Siswa Kelas VIII A SMP Negeri 1 Ngrayun Tahun Pelajaran 2013/2014". Peneliti akan menerapkan tipe NHT dengan pertimbangan karena menurut Anita Lie (2010:59) pada tipe ini mempunyai keunggulan dapat mengoptimalkan partisipasi siswa. Dalam pelaksanaannya pembelajaran kooperatif tipe NHT memberikan kesempatan kepada siswa untuk saling membagikan ide-ide dan mempertimbangkan jawaban yang paling tepat. Selain itu teknik ini juga mendorong siswa untuk meningkatkan semangat kerjasama mereka.

\section{Metode Penelitian}

Penelitian ini dilakukan di SMP Negeri 1 Ngrayun yang berada di
Kecamatan Ngrayun, Kabupaten Ponorogo Semester Genap Tahun Pelajaran 2013/2014. Penelitian ini ingin meningkatkan motivasi dan prestasi belajar siswa kelas VIII A SMP Negeri 1 Ngrayun. Sejalan dengan masalah dan tujuan yang ada, penelitian ini dilaksanakan dengan menerapkan penelitian tindakan kelas atau Classroom Action Research yang meliputi empat tahap yaitu perencanaan tindakan, pelaksanaan tindakan, observasi dan refleksi.

Teknik pengumpulan data yang digunakan dalam penelitian ini adalah wawancara, tes, observasi dan angket. Untuk menjamin kepercayaan data yang diperoleh melalui penelitian maka perlu dilakukan validitas data.

Triangulasi yang digunakan dalam penelitian ini adalah adalah triangulasi metode dilakukan dengan cara membandingkan informasi atau data.

Teknik analisis data dalam penelitian ini menggunakan teknik deskriptif yang dilakukan dengan tiga cara, yaitu: pengumpulan data, reduksi data, penyajian data dan penarikan kesimpulan.

\section{Hasil dan Pembahasan}

Hasil observasi awal menunjukkan bahwa kegiatan pembelajaran IPS di kelas VIII A SMP Negeri 1 Ngrayun yang dilakukan oleh guru masih konvensional dan monoton. Dalam kegiatan pembelajaran IPS guru cenderung menggunkan metode ceramah, sehingga kegiatan pembelajaran masih didominasi guru dan kurang memberikan peran aktif siswa dalam kegiatan pembelajaran. Hal 
Avaliable online at http://e-journal.unipma.ac.id/index.php/gulawentah

demikian membuat siswa cepat bosan dan kurang tertarik dalam mengikuti kegiatan pembelajaran sehingga menyebabkan siswa kurang termotivasi dalam belajar yang akhirnya menyebabkan rendahnya prestasi belajar siswa. Berdasarkan hal tersebut dapat dikatakan bahwa guru kurang tepat dalam memilih metode pembelajaran.

Pemilihan model pembelajaran hendaknya disesuaikan dengan kondisi dan situasi kelas serta tujuan yang ingin dicapai. Sulit untuk menentukan model pembelajaran yang mampu memecahkan semua masalah dalam pembelajaran, tetapi model pembelajaran dapat membantu siswa dalam mempelajari materi dan makna dari materi yang diajarkan. Agar siswa lebih produktif dalam belajar, maka hendaknya guru memberikan kesempatan kepada siswa untuk tumbuh dan berkembang sesuai dengan kreativitas mereka sendiri sehingga pemilihan model pembelajaran juga harus mengikuti kebutuhan siswa.

Penggunaan model pembelajaran yang tepat mampu memberikan peran aktif siswa sehingga nantinya diharapkan dapat meningkatkan motivasi belajar siswa. Demikian pula dengan adanya kerjasama dalam pembelajaran baik kerjasama antar siswa maupun antara guru dan siswa diharapkan dapat membantu siswa untuk lebih memahami materi yang diberikan sehingga memperoleh skor di atas KKM.

Salah satu model pembelajaran yang dapat digunakan adalah model pembelajaran kooperatif tipe Numbered Heads Together (NHT). Pembelajaran kooperatif tipe Numbered Heads Together (NHT) merupakan salah satu tipe pembelajaran kooperatif yang menekankan pada struktur khusus yang dirancang untuk mempengaruhi pola interaksi siswa dan memiliki tujuan untuk meningkatkan penguasaan akademik. (Ibrahim, 2000:28).

Struktur yang dikembangkan oleh Kagan ini menghendaki siswa belajar saling membantu dalam kelompok kecil dan lebih dicirikan oleh penghargaan kooperatif daripada penghargaan individual. Ada struktur yang memiliki tujuan umum untuk meningkatkan penguasaan isi akademik dan ada pula struktur yang tujuannnya untuk mengajarkan keterampilan sosial (Ibrahim, 2000:25). Keterampilan yang dimaksud antara lain berbagi tugas, aktif bertanya, menghargai pendapat orang lain, mau menjelaskan ide atau pendapat, bekerja dalam kelompok dan sebagainya.

Dalam penggunaan model pembelajaran kooperatif tipe Numbered Heads Together (NHT) ini, secara garis besar tindakan yang akan diterapkan adalah sebagai berikut:

a. Pendahuluan

Pada kegiatan pendahuluan ini, (1) guru membagi siswa menjadi beberapa kelompok atau tim yang beranggotakan 4-5 orang dan memberi mereka nomor, sehingga tiap siswa dalam kelompok tersebut memiliki nomor yang berbeda, (2) menginformasikan materi yang akan dibahas atau mengaitkan materi yang dibahas dengan materi yang lalu, (3) mengkomunikasikan tujuan pembelajaran dan menjelaskan apa yang akan dilaksanakan, (4) memotivasi siswa agar timbul rasa ingin tahu siswa tentang materi yang akan dipelajari. 
Avaliable online at http://e-journal.unipma.ac.id/index.php/gulawentah

b. Kegiatan Inti

Pada kegiatan inti ini meliputi; (1) guru menjelaskan materi secara sederhana, (2) guru mengajukan suatu pertanyaan kepada siswa, (3) siswa memikirkan pertanyaan yang diajukan oleh guru, (4) siswa berpikir bersama untuk menggambarkan dan meyakinkan bahwa tiap anggota kelompok mengetahui jawaban tersebut, (5) guru menyebutkan (memanggil) suatu nomor dari salah satu kelompok secara acak, (6) siswa dari tiap kelompok dengan nomor yang sama mengangkat tangan, (7) siswa menyiapkan jawaban untuk seluruh kelas, ditanggapi oleh kelompok lain, (8) jika jawaban dari hasil diskusi kelas sudah dianggap betul siswa diberi kesempatan untuk mencatat dan apabila jawaban masih salah, guru akan mengarahkan, (9) guru memberikan pujian kepada siswa atau kelompok yang menjawab betul.

c. Penutup

Pada tahap penutup ini meliputi; (1) guru membimbing siswa menyimpulkan materi, (2) siswa diberikan tugas untuk diselesaikan dirumah dan mengerjakan kuis.

Berdasarkan hasil observasi pada siklus I, hasil yang diperoleh adalah sebagai berikut: (1) dalam kegiatan pendahuluan guru belum menghubungkan pelajaran yang sekarang dengan pelajaran yang terdahulu, (2) guru dalam mengatur siswa dalam kelompok-kelompok belajar belum optimal, hal ini terlihat bahwa situasi kelas masih gaduh dalam pembentukan kelompok, (3) guru belum memberikan pengakuan atau penghargaan terhadap siswa atau kelompok yang menjawab betul, (4) guru dalam membuat rangkuman masih tampak tergesa-gesa sehingga siswa tidak sempat mencatat semua hal-hal yang dibutuhkan, (5) sebagian siswa belum dapat bekerjasama dengan baik dalam kelompoknya. Ada siswa yang hanya diam dan masa bodoh sehingga cenderung menggantungkan diri pada anggota kelompok yang pintar, (6) masih kurangnya rasa ingin tahu siswa, hal ini terlihat dari masih sedikitnya siswa yang bertanya, (7) siswa belum berani menyampaikan pendapatnya dalam menanggapi pendapat dari kelompok lain. Berdasarkan hal tersebut diatas diketahui bahwa pembelajaran pada siklus I belum berhasil sehingga perlu dilakukan tindakan ke siklus berikutnya yaitu siklus II dengan beberapa perbaikan.

Berdasarkan hasil observasi peneliti pada siklus II diperoleh hasil sebagai berikut: (1) kegiatan pendahuluan dapat dilakukan guru dengan baik, guru dalam memberikan motivasi kepada siswa supaya tertarik mengikuti pembelajaran sudah lebih baik dibanding pada pertemuan sebelumnya. Dalam kegiatan pendahuluan guru sudah mampu menyampaikan tujuan pembelajaran dengan jelas dan mampu menghubungkan pelajaran yang akan dipelajari dengan pelajaran yang terdahulu, (2) pengaturan kelompok dapat dilakukan dengan baik sehingga tidak terjadi kegaduhan. Namun guru belum mampu sepenuhnya memberikan bimbingan kepada kelompok untuk bekerjasama dengan baik, hal ini terlihat adanya dua kelompok yakni kelompok 1 
dan kelompok 4 yang belum mampu bekerjasama dengan baik, (3) guru memberikan penghargaan terhadap siswa yang menjawab pertanyaan guru dengan benar sehingga siswa terlihat lebih bersemangat dan termotivasi, (4) guru sudah mampu membuat rangkuman dengan baik sehingga siswa dapat mencatat semua hal-hal yang dibutuhkan, (5) masih ada siswa yang belum dapat bekerjasama dengan baik dalam kelompoknya. Hal ini terjadi pada kelompok 1 dan kelompok 4. Berdasarkan hal tersebut diatas diketahui bahwa pembelajaran pada siklus I sudah lebih baik dibanding siklus I, namun masih perlu dilakukan tindakan ke siklus berikutnya yaitu siklus III dengan beberapa perbaikan.

Berdasarkan hasil observasi peneliti pada siklus II diperoleh hasil sebagai berikut: (1) pada siklus III ini, guru sudah lebih optimal dalam menerapkan model pembelajaran kooperatif tipe Numbered Heads Together (NHT) dibanding dengan siklus II, hal ini dapat terlihat dari: guru dapat melaksanakan kegiatan pembelajaran dengan baik, guru dapat menyampaikan materi pembelajaran dengan jelas dan baik sehingga siswa terlihat sangat antusias mengikuti pembelajaran, guru juga dapat memberikan bimbingan kepada kelompok untuk bekerjasama dengan baik, selain itu guru juga memberikan penghargaan terhadap siswa yang menjawab pertanyaan guru dengan benar sehingga siswa terlihat lebih bersemangat dan termotivasi, serta guru mampu menutup kegiatan pembelajaran dengan baik dan tepat sesuai dengan alokasi waktu yang ditentukan, (2) siswa sudah dapat bekerjasama dengan baik dalam kelompoknya. Selain itu siswa juga terlihat lebih aktif dalam mengemukakan pendapatnya, (3) hasil angket motivasi belajar siswa menunjukkan secara klasikal mencapai $84,62 \%$, dan telah melampaui target yang ditentukan. (4) prestasi belajar siswa telah melampaui target yang ditentukan, dengan nilai rata-rata mencapai sebesar 80,38 dan ketuntasan klasikal mencapai $88,46 \%$. Berdasarkan hasil analisis observasi siklus III ini, maka diputuskan untuk berhenti pada siklus III atau tidak melanjutkan lagi ke siklus berikutnya.

Berdasarkan hasil dalam penelitian ini menunjukkan bahwa penerapan model pembelajaran kooperatif tipe Numbered Heads Together (NHT) dalam pembelajaran IPS menjadikan siswa merasa senang dan tertarik dalam mengikuti kegiatan pembelajaran serta mampu berbagi tugas, aktif bertanya, menghargai pendapat orang lain, mau menjelaskan ide atau pendapat, dan bekerjasama dalam kelompok.

Berdasarkan pelaksanaan tindakan siklus I, II dan III menunjukkan bahwa motivasi belajar siswa meningkat tiap siklusnya setelah adanya penerapan model pembelajaran kooperatif tipe Numbered Heads Together (NHT) dalam pembelajaran IPS.

Pengukuran terhadap motivasi belajar siswa setelah diterapkannya model pembelajaran kooperatif tipe Numbered Heads Together (NHT), pada siklus I skor rata-ratanya sebesar 126 atau $78,73 \%$, dengan rincian siswa yang 
Avaliable online at http://e-journal.unipma.ac.id/index.php/gulawentah

memperoleh skor $\geq 80 \%$ sebanyak 13 orang siswa atau mencapai $50 \%$, sedangkan yang memperoleh skor dibawah $80 \%$ sebanyak 13 orang siswa atau mencapai 50\%. Secara klasikal motivasi belajar siswa pada siklus I yang mencapai $\geq 80 \%$ hanya sebesar $50 \%$.

Motivasi belajar siswa pada siklus II meningkat dengan skor rata-rata sebesar 128,65 atau $80,41 \%$. Hal ini menunjukkan peningkatan dibanding pada siklus I yang hanya mencapai 126 atau $78,73 \%$. Pada siklus II ini, siswa yang memperoleh skor $\geq 80 \%$ sebanyak 18 orang siswa atau mencapai $69,23 \%$, sedangkan yang memperoleh skor dibawah $80 \%$ sebanyak 8 orang siswa atau mencapai 30,77\%. Meskipun mengalami peningkatan, tetapi secara klasikal motivasi belajar siswa pada siklus II yang mencapai $\geq 80 \%$ hanya sebesar 69,23\%, skor tersebut belum mencapai target yang ditentukan yakni $80 \%$.

Motivasi belajar siswa pada siklus III kembali mengalami peningkatan, dengan skor rata-rata mencapai sebesar 131,50 atau $82,19 \%$. Hal ini menunjukkan peningkatan dibanding pada siklus II yang hanya mencapai 128,65 atau $80,41 \%$. Pada siklus III siswa yang memperoleh skor $\geq 80 \%$ sebanyak 22 orang siswa atau mencapai $84,62 \%$, sedangkan yang memperoleh skor dibawah $80 \%$ sebanyak 4 orang siswa atau mencapai $15,38 \%$. Dengan demikian secara klasikal motivasi siswa yang mencapai $\geq 80 \%$ mencapai $84,62 \%$, dan telah melampaui target yang ditentukan.
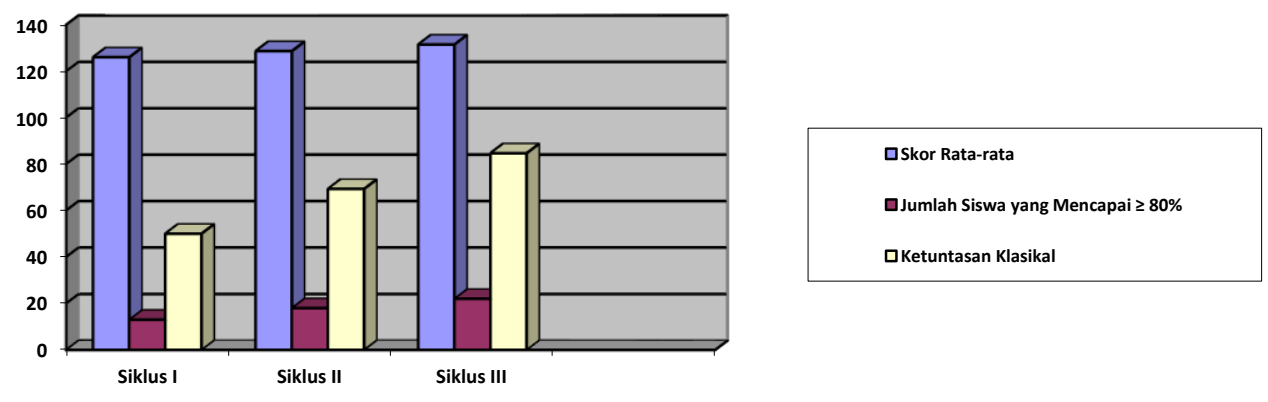

\section{Gambar 1. Grafik perbandingan motivasi belajar siswa pada siklus I, II dan III}

Menurut Hamalik (2013:119-120) salah satu upaya yang dapat dilakukan guru untuk meningkatkan motivasi belajar siswa antara lain dengan pemberian insentif, yaitu melalui: (1) umpan balik hasil-hasil tes, (2) pemberian hadiah dan dorongan secara lisan dan tertulis, (3) pemberian komentar terhadap hasil pekerjaan siswa, (4) persaingan dan kerjasama. Oleh karena itu perlu adanya model pembelajaran yang menekankan kerjasama dan adanya penghargaan terhadap siswa sehingga menjadikan kondisi pembelajaran yang menyenangkan. Menurut Kagan, model pembelajaran kooperatif tipe Numbered Heads Together (NHT) menghendaki siswa belajar saling membantu dalam kelompok kecil dan lebih dicirikan oleh penghargaan kooperatif daripada penghargaan individual (Ibrahim, 2000:25). Upaya peningkatan motivasi belajar siswa melalui pemberian insentif 


\section{gulawentah: Jurnal Studi Sosial}

Volume 2 Nomor 1 Juli 2017 hal 1-12

Avaliable online at http://e-journal.unipma.ac.id/index.php/gulawentah

terlaksana melalui penerapan model pembelajaran kooperatif tipe Numbered Heads Together (NHT), sehingga hal tersebut dapat meningkatkan motivasi belajar siswa pada tiap siklusnya.

Terkait dengan hal tersebut, hasil pelaksanaan tindakan pada siklus I menunjukkan ketuntasan secara klasikal angket motivasi belajar mencapai sebesar 50\%, kemudian pada siklus II meningkat menjadi sebesar 69,23\%, tetapi belum mencapai target yang ditentukan yakni $80 \%$. Motivasi belajar siswa pada siklus III kembali mengalami peningkatan, secara klasikal motivasi belajar siswa mencapai $84,62 \%$, skor tersebut telah melampaui target yang ditentukan. Meningkatnya motivasi belajar siswa dikarenakan siswa sudah terbiasa dengan model pembelajaran kooperatif tipe Numbered Heads Together (NHT) dalam pembelajaran IPS, selain itu siswa dapat saling bekerjasama dan adanya penghargaan sehingga menjadikan siswa lebih termotivasi dalam kegiatan pembelajaran.

Berdasarkan tindakan yang dilakukan pada siklus I, II dan III menunjukkan bahwa penerapan model pembelajaran kooperatif tipe Numbered Heads Together (NHT) dalam pembelajaran IPS dapat meningkatkan prestasi belajar siswa kelas VIII A SMP Negeri 1 Ngrayun.

Prestasi belajar siswa pada kondisi awal menunjukkan bahwa nilai rata-rata dari keseluruhan siswa kelas VIII A yang berjumlah 26 siswa adalah sebesar 68,27 dengan ketuntasan klasikal sebesar $53,85 \%$. Setelah dilakukan tindakan pada siklus I, nilai siswa mengalami peningkatan dengan nilai rata-rata sebesar 73,85 dengan ketuntasan klasikal sebesar $65,38 \%$. Meskipun mengalami peningkatan prestasi belajar dari kondisi awal ke siklus I, akan tetapi hasil tersebut belum mencapai ketuntasan klasikal yang ditentukan sebesar $85 \%$.

Prestasi belajar siswa pada siklus II meningkat dengan nilai rata-rata mencapai sebesar 74,23 dengan ketuntasan klasikal sebesar 69,23\%. Meskipun pada siklus II prestasi belajar siswa kembali menunjukkan peningkatan, namun demikian secara klasikal masih belum tuntas belajar.

Prestasi belajar siswa pada siklus III mengalami peningkatan kembali, dengan nilai rata-rata mencapai sebesar 80,38 dengan ketuntasan klasikal mencapai $88,46 \%$. Berdasarkan prestasi belajar siklus III secara klasikal siswa kelas VIII A telah tuntas belajar. 

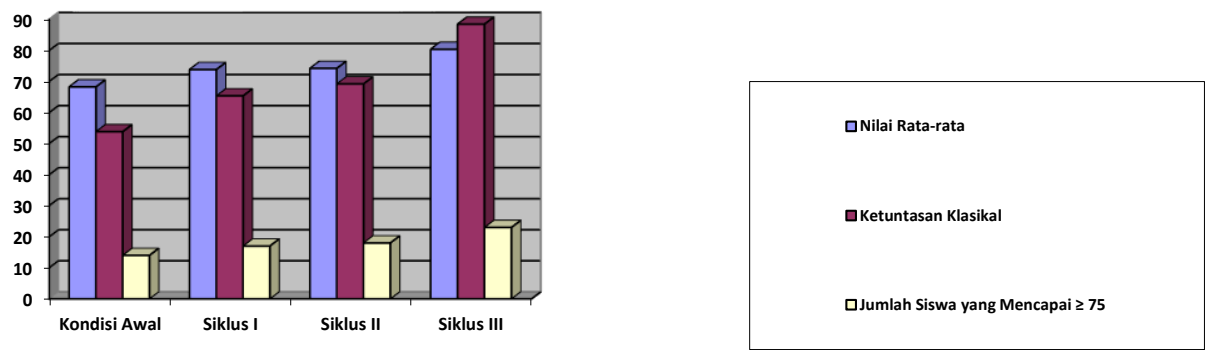

Gambar 2. Grafik perbandingan prestasi belajar siswa pada kondisi awal, siklus I, II dan III

Ibrahim (2000:28) menyatakan bahwa pembelajaran kooperatif tipe Numbered Heads Together (NHT) merupakan salah satu tipe pembelajaran kooperatif yang menekankan pada struktur khusus yang dirancang untuk mempengaruhi pola interaksi siswa dan memiliki tujuan untuk meningkatkan penguasaan akademik. Penguasaan akademik merupakan salah satu bentuk prestasi belajar. Menurut Winkel (1984:51), prestasi belajar adalah bukti keberhasilan yang dicapai.

Berdasarkan hal tersebut, setelah dilaksanakan penerapan model pembelajaran kooperatif tipe Numbered Heads Together (NHT) dalam pembelajaran IPS menunjukkan bahwa telah terjadi peningkatan prestasi belajar siswa dari siklus I, II sampai siklus III. Pada siklus I secara klasikal ketuntasan belajar siswa sebesar $65,38 \%$, kemudian pada siklus II meningkat menjadi sebesar 69,23\%, dan pada siklus III kembali menunjukkan peningkatan ketuntasan klasikal mencapai 88,46\%.

Hal tersebut sejalan dengan hasil penelitian yang dilakukan oleh Emy Rosyida (2012) dan Mulyati (2013) yang menyimpulkan bahwa penerapan model pembelajaran kooperatif tipe Numbered Heads Together (NHT) dapat meningkatkan prestasi belajar dan motivasi siswa.

Berdasarkan uraian tersebut dapat ditarik sebuah kesimpulan bahwa terdapat hubungan antara teori dan hasil temuan dalam penelitian ini, maupun penelitian yang telah dilakukan oleh peneliti yang lain yaitu penerapan model pembelajaran kooperatif tipe Numbered Heads Together (NHT) dapat meningkatkan motivasi dan prestasi belajar siswa.

\section{Kesimpulan}

Berdasarkan hasil penelitian dan pembahasan dapat ditarik kesimpulan hal-hal sebagai berikut:

Berdasarkan hasil penelitian, dengan menerapkan model pembelajaran kooperatif tipe Numbered Heads Together (NHT) dalam pembelajaran IPS terbukti dapat meningkatkan motivasi belajar siswa kelas VIII A SMP Negeri 1 Ngrayun. Peningkatan motivasi belajar siswa dapat terlihat pada tiap siklus. Berdasarkan hasil angket motivasi belajar siswa, pada siklus I 


\section{gulawentah: Jurnal Studi Sosial}

Volume 2 Nomor 1 Juli 2017 hal 1-12

Avaliable online at http://e-journal.unipma.ac.id/index.php/gulawentah

pencapaian siswa sebesar $50 \%$, siklus II meningkat menjadi sebesar $69,23 \%$, dan pada siklus III kembali mengalami peningkatan menjadi sebesar $84,62 \%$.

Berdasarkan hasil penelitian, dengan menerapkan model pembelajaran kooperatif tipe Numbered Heads Together (NHT) dalam pembelajaran IPS terbukti dapat meningkatkan prestasi belajar siswa kelas VIII A SMP Negeri 1 Ngrayun. Peningkatan prestasi belajar siswa dapat terlihat pada tiap siklus. Prestasi belajar siswa pada kondisi awal menunjukkan bahwa nilai rata-rata sebesar 68,27 dengan ketuntasan klasikal sebesar 53,85\%. Setelah dilakukan tindakan pada siklus I, nilai siswa mengalami peningkatan dengan nilai rata-rata sebesar 73,85 dengan ketuntasan klasikal sebesar 65,38\%. Pada siklus II prestasi belajar siswa meningkat dengan nilai rata-rata mencapai sebesar 74,23 dengan ketuntasan klasikal sebesar 69,23\%, dan pada siklus III mengalami peningkatan kembali, dengan nilai rata-rata mencapai sebesar 80,38 dengan ketuntasan klasikal mencapai $88,46 \%$.

Penerapan model pembelajaran kooperatif tipe Numbered Heads Together (NHT) dalam pembelajaran IPS yang dilaksanakan dalam tiga siklus terbukti telah meningkatkan motivasi dan prestasi belajar siswa kelas VIII A SMP Negeri 1 Ngrayun. Penggunaan model pembelajaran yang tepat mampu memberikan peran aktif siswa sehingga nantinya diharapkan dapat meningkatkan motivasi belajar siswa. Demikian pula dengan adanya kerjasama dalam pembelajaran baik kerjasama antar siswa maupun antara guru dan siswa diharapkan dapat membantu siswa untuk lebih memahami materi yang diberikan sehingga dapat memperoleh prestasi belajar di atas KKM. Penerapan model pembelajaran kooperatif tipe Numbered Heads Together (NHT) dalam pembelajaran IPS menjadikan siswa merasa senang dan tertarik dalam mengikuti kegiatan pembelajaran serta mampu berbagi tugas, aktif bertanya, menghargai pendapat orang lain, mau menjelaskan ide atau pendapat, dan bekerjasama dalam kelompok. Kualitas pembelajaran meningkat dengan adanya penerapan model pembelajaran kooperatif tipe Numbered Heads Together (NHT) ini, hal ini dapat terlihat dari meningkatnya motivasi dan prestasi belajar siswa tiap siklusnya. Berdasarkan hal tersebut dapat menjadi bahan pertimbangan bagi guru untuk menerapkan model pembelajaran ini dalam kegiatan pembelajaran seharihari.

Guru dalam kegiatan pembelajaran hendaknya dapat menggunakan model pembelajaran kooperatif tipe Numbered Heads Together (NHT) untuk meningkatkan motivasi dan prestasi belajar IPS.

Guru perlu lebih meningkatkan pemahaman dan wawasannya tentang berbagai model pembelajaran yang sekiranya mampu untuk meningkatkan kualitas pembelajaran.

Kepala Sekolah perlu lebih mengupayakan peningkatan profesionalisme guru melalui pelatihan 


\section{gulawentah: Jurnal Studi Sosial}

Volume 2 Nomor 1 Juli 2017 hal 1-12

Avaliable online at http://e-journal.unipma.ac.id/index.php/gulawentah

yang berkaitan dengan model model pembelajaran, khususnya mengenai implementasi model pembelajaran kooperatif tipe Numbered Heads Together (NHT) untuk meningkatkan motivasi dan prestasi belajar IPS.

Dinas pendidikan dapat memfasilitasi terselenggaranya pelatihan pelatihan bagi pengembangan profesionalisme guru, khususnya yang berkaitan dengan penggunaan model pembelajaran yang dapat meningkatkan motivasi dan prestasi belajar siswa, sehingga nantinya akan dapat meningkatkan kualitas pendidikan.

\section{Daftar Pustaka}

Gunawan, R. (2013). Pendidikan IPS : Filosofi, Konsep dan Aplikasi. Bandung: Alfabeta.

Huda, M. (2011). Cooperative Learning : Metode, Teknik, Struktur dan Model Penerapan. Yogyakarta: Pustaka Pelajar.

Hamalik, O. (2013). Kurikulum dan Pembelajaran. Jakarta: Bumi Aksara.

Isjoni. (2011). Cooperative Learning : Kemampuan Mengembangkan Kemampuan Belajar Berkelompok. Bandung: Alfabeta.

Lie, A. (2010). Cooperative Learning : Mempraktikkan Cooperative Learning di Ruang-Ruang Kelas. Jakarta: Grasindo.

Muslimin, M. (2000). Pembelajaran Kooperatif. Surabaya: University Press.

Mulyati. (2013). Peningkatan Kualitas Pembelajaran Akuntansi melalui Penerapan Model Pembelajaran Kooperatif Tipe Numbered Heads
Together (NHT) Kelas XI IPS SMA

Negeri 3 Sragen Tahun Pelajaran 2012/2013. Tesis tidak diterbitkan. Surakarta: Universitas Sebelas Maret Surakarta.

Musadad, A. A. dan Wasino. (2012). "Model Pelatihan IPS Sejarah Berbasis Pendidikan Multikultural untuk Guru SMP”. Paramita. Vol. 22 No. 2.

Purwanto, A.J. (1994). "Tantangan Dalam Pembelajaran Sejarah Interaktif Edukatif“. Historika. Tahun ke VI No.8.

Rosyida, E. (2012). Implementasi Model Pembelajaran Kooperatif Numbered Heads Together (NHT) Terhadap Prestasi Belajar Ekonomi Ditinjau dari Motivasi Belajar Siswa Kelas X SMA Negeri 1 Ponorogo Tahun Pelajaran 2011/2012. Tesis tidak diterbitkan. Surakarta: Universitas Sebelas Maret Surakarta.

Solihatin, E. dan Raharjo. (2011). Coopeative Learning: Analisis Model Pembelajaran IPS. Jakarta: Bumi Aksara.

Winkel, W.S. (1984). Psikologi Pendidikan. Jakarta: Rineka Cipta. 